JKEP

Vol 4, No 1, Mei 2019

ISSN: 2354-6042 (Print)

ISSN : 2354-6050 (Online)

\title{
Kontrol Diri Dengan Motivasi Belajar Anak Usia Remaja
}

\author{
Vania Puspa Zerlinda Setiadi, Agus Purnama \\ Sekolah Tinggi Ilmu Kesehatan Indonesia Maju \\ Email:vaniapuspaz.s@gmail.com,purnama.agus@gmail.com.
}

\author{
Artikel history \\ Dikirim, Jan $10^{\text {th }}, 2019$ \\ Ditinjau, Feb 04 $4^{\text {th }}, 2019$ \\ Diterima, Maret $20^{\text {th }}, 2019$
}

\begin{abstract}
In a student who does not have good self-control in fulfilling all of her obligations in her academic process at school, the teenager will tend to have difficulty to fulfill all her demands in motivating her learning. The purpose of this study was to determine the existence of self control Relationships with Motivation Learning junio high school adolescent children in Depok. This research design uses descriptive quantitative with cross-sectional design. While the samples taken are all students as many as 79 students using simple total Sampling technique. Instrument data collection is a questionnaire. The result is high self-control and high learning motivation can be a great opportunity, with a percentage of high self control 42 students (62,0\%) and high learning motivation39 students (59,5\%), The result of corelasi spearman test shows the result ( $p$ value=0,005), from Odds Ratio value can have a chance 3,750. and it shows the existence of self control relationship with learning motivation of adolescent child. Advice for the parent hopefully they can motivate their children to study harder.
\end{abstract}

Keywords $\quad$ : Adolescent Children In; Self-Contro;, Learning Motivation

\begin{abstract}
Abstrak
Pada seorang pelajar yang tidak memiliki kontrol diri yang baik dalam memenuhi segala kewajibannya dalam proses akademiknya di sekolah, maka remaja tersebut akan cenderung mengalami kesulitan untuk memenuhi segala tuntutannya dalam memotivasi belajarnya. Tujuan penelitian ini adalah mengetahui adanya Hubungan Kontrol Diri dengan Motivasi Belajar anak usia remaja SMP di sekolah Master Depok. Desain penelitian ini menggunakan deskriptif kuantitatif dengan rancangan cross-sectional. Sampel yang diambil adalah seluruh siswa sebanyak 79 siswa menggunakan teknik Simple Total Sampling. Instrument pengumpulan data adalah kuesioner. Hasil penelitian ini menunjukkan bahwa kontrol diri tinggi dan motivasi belajar tinggi dapat berpeluang besar, dengan persentase pada kontrol Diri Tinggi 42 siswa (62,0\%) dan Motivasi Belajar Tinggi 39 siswa (59,5\%). Analisa penelitian uji korelasi Spearmen menunjukan hasil ( $p$ value $=0,005$ ), dari nilai Odds Ratio dapat berpeluang sebesar 3,750. Hal ini menunjukkan adanya hubungan kontrol diri dengan motivasi belajar Anak usia Remaja. Saran bagi orangtua terutama ibu dapat selalu memberikan motivasi dalam belajar kepada anaknya.
\end{abstract}

Kata Kunci : Anak Remaja; Kontrol Diri; Motivasi Belajar 


\section{PENDAHULUAN}

Pendidikan di Indonesia perlu penanganan yang sangat serius jika Indonesia ingin memiliki SDM yang berkualitas sehingga dapat bersaing di wilayah global. Kebijakan-kebijakan baru dari Dinas pendidikan sekarang terus disosialisasikan seperti kurikulum baru 2013 ujian sertifikat guru dan berbagai bentuk beasiswa bagi siswa tertentu.

Kontrol diri adalah kemampuan mengendalikan perasaan, pikiran dan tindakan agar dapat menahan dorongan dari dalam maupun luar sehingga seseorang mampu bertindak dengan benar. Kontrol diri merupakan kemampuan seseorang untuk memilih hasil atau suatu tindakan pada sesuatu yang diyakini atau disetujuinya, kontrol diri dalam menentukan pilihan akan berfungsi baik dengan adanya suatu kesempatan, kebebasan atau kemungkinan pada diri individu berbagai kemungkinan dan tindakan (Dadang, 2014).

Kontrol diri berkaitan seseorang mengendalikan emosinya serta dorongandorongan negatif dalam dirinya ke arah yang lebih positif, bermanfaat dan dapat diterima secara sosial. Saat berada di lingkungan sosialnya ketika berinteraksi dengan orang lain seseorang akan cenderung berusaha untuk menampilkan perilaku yang dianggap paling tepat dan benar bagi diri dan lingkungan sekitarnya (Dini, 2013). Kontrol diri berperan dalam kreativitas seseorang pada saat individu bekerja. Menyatakan bahwa kontrol diri yang dilakukan karena individu hidup bersama kelompok sehingga dalam memuaskan keinginannya individu harus mengontrol perialakunya. Salah satu faktor yang dapat mempengaruhi kontrol diri seseorang adalah faktor lingkungan (Donny, 2015).

Motivasi belajar adalah keseluruhan daya penggerak dalam diri siswa yang menimbulkan kegiatan belajar yang menjamin kelangsungan dari belajar, sehingga tujuan yang diinginkan dapat tercapai. Motivasi dan belajar merupakan dua hal yang saling mempengaruhi, belajar dimana terdapat perubahan tingkah laku secara relatif permanen dan secara potensial terjadi sebagai hasil dari praktik atau penguatan yang dilandasi untuk dapat mencapai tujuan tertentu (Esterina, 2014).

Motivasi belajar juga dipengaruhi oleh usia, Usia remaja merupakan usia peralihan dari anak-anak menjadi dewasa dimana batas usia pada masing-masing tahap perkembangan tidak berbatas tegas karena setiap tahapan tumbuh kembang berjalan secara berkesinambungan (Eva, 2015).

Remaja adalah masa yang penuh dengan permasalahan dan masa terjadinya krisis 
identitas atau pencarian identitas diri. Remaja merupakan periode transisi antara masa anak-anak ke masa dewasa atau masa belasan tahun atau seseorang yang menunjukkan tingkah laku tertentu seperti tidak mudah untuk diatur dan mudah terpengaruh perasaan (Eviana, 2014). Keberadaan motivasi sangatlah diperlukan dalam belajar karena motivasi merupakan syarat mutlak yang harus dimiliki dalam belajar (Herasti, 2014).

Di negara maju seperti Amerika Serikat dan Eropa insidens kesulitan belajar kurang lebih $10-15 \%$ dan populasi anak sekolah insidensi pada anak laki-laki lebih banyak dibandingkan pada anak perempuan sebesar 8:1. Prevalensi dari kesulitan belajar sangar bervariasi, di Amerika Serikat melalui data National Health Interview Survey didapatkan 6,5 \% pada anak usia sekolah dan pada tahun 2001 meningkat 7,7\%. Berdasarkan laporan The United Nations Development proframme (UNDP) tahun 2011 yang mengumumkan peringkat indeks pembangunan manusia (IPM) atau Human Development Index (HDI), Indonesia berada pada peringkat ke-124 dari 187 negara didunia, peringkat tersebut mengalami penurunan dari tahun sebelumnya 2010 yaitu peringkat ke-108 pada 2010, mengalami penurunan sebanyak 16 peringkat menjadi peringkat ke 124 pada tahun 2011. Walaupun angka IPM Indonesia dinyatakan naik dari 0,600
(2010) menjadi 0,617 (2011), namun peringakat IPM Indonesia menurun drastis 16 peringkat.

Hal ini menunjukkan bahwa pendidikan di Indonesia masih tertinggal dengan negaranegara lain. Dalam ruang lingkup ragional ASEAN, negara berperingkat tertinggi dalam pencapaian Indeks pembangunan Manusia (IPM) adalah Singapura dengan nilai 0,866, Brunei Darussalam dengan nilai 0,833, Malaysia 0,761, Thailand 0,682 dan Filipina 0,644. Data yang diperoleh dari Badan Pusat Statistik Nasional pada tahun 2010 provinsi DKI Jakarta menempati peringkat teratas dengan nilai IPM 77,60 sedangkan provinsi dengan peringkat terendah yaitu provinsi papua dengan nilai IPM 64,94 dan pada provinsi Jawa Barat di peringkat 15 dengan nilai IPM 72,29 dari 33 provinsi yang ada di Indonesia (Kilas, 2017).

Di provinsi Jawa Barat dari data BPS (Badan Pusat Statistik) provinsi Jawa Barat pada tahun 2005, indeks pendidikan tertinggi ada di Kota Bekasi dengan nilai 90,03, terendah kabupaten Indramayu dengan nilai 66,98. Wakil ketua Dewan Perwakilan Rakyat Daerah (DPRD) kota Depok Muhammad Supariyono menilai bahwa mutu pendidikan di kota Depok belum sesuai dengan visi-misi pembangunan kota, berdasarkan data yang dimiliki bila dirata-ratakan tidak semua 
warga Depok lulus sekolah tingkat sekolah menengah atas (SMA), Karena pendidikan di Depok baru sampai 11,3 tahun padahal wajib belajarnya 12 tahun. Ada beberapa faktor penyebab usia belajar di Depok pada angka 11,3 tahun, diantaranya pola pikir warga terhadap pendidikan yang dirasa belum begitu penting, selain itu faktor ekonomi dan faktor budaya (Lailatur, 2008).

Salah satu sekolah yang berada di depok yaitu di sekolah Masjid Terminal Depok nilai rata-rata hasil belajar siswa dari kelas 1,2 dan 3 memiliki nilai rata-rata belajar sekitar 6,5-8, dan rata-rata memiliki nilai yang kurang dan sebagian memiliki nilai yang cukup baik, dan dari kedisiplinan siswa disana rata-rata sebagian besar memiliki rasa kedisplinan sangat rendah sekitar $50 \%$ sebagian yang memiliki kediplisinan baik $50 \%$ dalam peraturan yang diberikan oleh sekolah. Seperti memberikan berbagai alternatif pelayanan untuk pemenuhan kebutuhan anak dan mempersiapkan masa depannnya sehingga menjadi masyarakat melalui yang dilakukan oleh pemerintah. Sebelum pihak pemerintah dan swasta berpartisipasi, sebenarnya sudah banyak lembaga swadaya masyarakat (LSM) yang berupaya menjawab kebutuhan anak penelantar dengan mendirikan yayasan sosial, contohnya Yayasan Bina Insan Mandiri
Depok yang lebih dikenal dengan sebutan sekolah MASTER (Masjid Terminal).

Berdasarkan hasil studi pendahuluan yang telah dilakukan penulis di Sekolah Masjid Terminal Depok, didapatkan data dari teknik wawancara sebagian besar motivasi belajar siswa masih kurang, dan dalam mengkontrol dirinya siswa masih belum mampu sehingga dapat menimbulkan motivasi belajar yang rendah. Oleh karena itu, penulis tertarik untuk meneliti apakah kontrol diri berhubungan dengan motivasi belajar pada anak usia remaja SMP di Sekolah Masjid Terminal Depok.

\section{METODE}

Desain penelitian yang digunakan pada penelitian ini adalah deskriptif kuantitatif dengan pendekatan cross sectional yaitu penelitian untuk mempelajari dinamika korelasi antara faktor-faktor risiko dengan efek, dengan cara pendekatan, observasi atau pengumpulan data sekaligus pada suatu saat (Metro, 2017).

Penelitian ini terdiri dari 1 variabel bebas dan 1 variabel terikat. Variabel bebas (independent) dalam penelitian ini yaitu kontrol diri, sedangkan variabel terikat (dependent) dalam penelitian ini adalah motivasi belajar. Variabel kontrol diri dimaksud dalam penelitian ini adalah menggambarkan sejauh mana individu tersebut dapat mengendalikan perasaan dan 
pikiran agar dapat menahan dorongan dari luar maupun dalam luar sehingga mampu bertindak dengan benar. Variabel proses motivasi belajar adalah dorongan individu dalam meningkatkan prestasinya, dengan menggunakan lembar kuesioner (Molazem, 2016).

Populasi penelitian adalah keseluruhan objek penelitian atau yang akan diteliti (Nediawati, 2016). Populasi dalam penelitian ini adalah anak remaja SMP master dari kelas 7, 8, 9 yaitu sebanyak 79 siswa. Sampel penelitian adalah subjek yang diteliti dan dianggap mewakili seluruh populasi (Metro, 2017). Pengambilan sampel dalam penelitian ini menggunakan teknik total sampling dari bulan SeptemberDesember 2017.

Alat pengumpulan data dalam penelitian ini menggunakan data primer. Data primer didapatkan dari kuesioner dan lembar observasi yang diberikan kepada siswa. Alat ukur untuk kontrol diri dan motivasi belajar kuesioner yang telah dilakukan uji validitas dan reliabilitas.

Analisis univariat dalam penelitian ini berupa karakteristik responden (jenis kelamin, usia dan pekerjaan orang tua), variable kontrol diri dan motivasi belajar. Penelitian ini melihat hubungan kontrol diri dengan motivasi belajar. Jenis data kontrol diri dan motivasi belajar adalah ordinal sehingga analisis yang digunakan adalah uji mann-whitney dengan menggunakan level of significance ( $\boldsymbol{\alpha}$ : alpha) sebesar 5\% $(0,05)$.

\section{HASIL DAN PEMBAHASAN}

\section{Gambaran Karakteristik Responden}

Berdasarkan Jenis Kelamin, Umur, dan

\section{Pekerjaan Orang Tua}

Hasil penelitian ini didapatkan bahwa jenis kelamin laki-laki perempuan lebih banyak dari pada jenis kelamin laki-laki dengan perbandingan laki-laki $41,8 \%$ perempuan $58,2 \%$. Dimana jenis kelamin perempuan mendominasi sebesar 58,2\% yang artinya lebih banyak murid perempuan dibandingkan murid laki-laki disekolah SMP Master Depok.

Hasil penelitian ini sejalan dengan Eva (2015) dalam penelitian berjudul Pengaruh Penyuluhan terhadap pengetahuan tentang kesehatan reproduksi remaja siswa kelas VII Di SMP N 14 yogyakarta, dinyatakan bahwa ternyata jenis kelamin perempuan lebih banyak dari pada jenis kelamin lakilaki dengan perbandingan laki-laki 46,6\% dan perempuan $53,4 \%$. Dimana jenis kelamin perempuan lebih mendominasi dibandingkan jenis kelamin laki-laki (Eva, 2015).

Hasil penelitian ini didapatkan bahwa umur siswa dapat terlihat pada usia 12 tahun $15,2 \%$ usia 13 tahun 30,4 usia 14 tahun $43,0 \%$ dan pada usia 15 tahun $11,4 \%$ 
.Dimana ternyata disekolah SMP Master Depok lebih dominan siswanya berusia 14 tahun sebesar $41,8 \%$.

Hasil penelitian menurut Septy (2013) menyatakan bahwa siswa SMP Negri 1 Ciseeng rata-rata berusia 12 tahun, dengan perbandingan usia 11 tahun $16,7 \%$, usia 12 tahun $45 \%$, usia 13 tahun $42 \%$, dan usia 14 tahun 5\%. Dimana ternyata siswa disekolah SMP Negeri 1 Cise6ng rata-rata berusia 12 tahun sebesar 45\% (Septy, 2013).

Hasil penelitian dari peneliti berdasarkan pekerjaan orang tua didapatkan bahwa pekerjaan orang tua rata-rata adalah Wiraswasta sebesar 48,1\%, selain itu pekerjaan orang tua lainnya yaitu pekerjaan Karyawan 3,8\% , Buruh 24,1\%, dan Tidak bekerja $24,1 \%$. Dimana dapat disimpulkan rata-rata pekerjaan orang tua pada siswa yang bersekolah diSMP Master Depok sebagai Wiraswasta.

Hasil penelitian menurut Fitiana (2015) dinyatakan bahwa pekerjaan orang tua murid di SMP Negeri 3 Adiwerna rata-rata adalah buruh sebesar 38\% dan pekerjaan orang tua lainnya sebagai Wiraswasta 35\%, PNS 20\% dan tidak bekerja 7\%. Maka penelitian ini tidak sejalan dengan peneliti (Fitiana, 2015)
Hasil penelitian ini didapatkan bahwa siswa yang memiliki kontrol diri tinggi sebanyak $62,0 \%$ dan yang memiliki kontrol diri rendah sebanyak $38,0 \%$. Dimana ternyata siswa diSMP Master Depok siswa memiliki kontrol diri yang tinggi sebesar 62,0\%.

Hasil penelitian sejalan dengan Resti (2007) dengan judul Hubungan antara kontrol diri dengan kecenderungan kecanduan media sosial pada remaja akhir dikatakan bahwa kontrol diri pada subjek penelitian menunjukkan bahwa sebanyak 42 siswa $53,17 \%$ memiliki tingkat kontrol diri tinggi dan 37 siswa 46,83\% memiliki kontrol diri sanggat tinggi. Hal ini menunjukkan bahwa rata-rata subjek memiliki kontrol diri yang tinggi, artinya siswa mampu mengendalikan tingkah laku dan menahan godaan yang muncul dari dalam diri sehingga mampu mengambil suatu tindakan untuk mencapai hasil yang diinginkan serta menghindari akibat yang tidak diinginkan (Partini dan Rifai, 2012)

\section{Gambaran Karakteristik Responden}

\section{Berdasarkan Kontrol Diri Siswa}


Gambaran Karakteristik Responden

\section{Berdasarkan Motivasi Belajar Siswa}

Pada penelitian ini didapatkan hasil dari motivasi belajar anak remaja yang memiliki motivasi belajar tinggi sebanyak 59,5\%, dan yang memiliki motivasi belajar rendah sebanyak $40,5 \%$. Dimana ternyata siswa disekolah SMP Master Depok memiliki Motivasi belajar tinggi sebesar 59,5\% .

Menurut penelitian dari Novi (2010) dengan berjudul pengaruh perilaku teman sebaya terhadap Motivasi belajar peserta didik di SMP Negeri 01 Ranah Batahan Kabupaten Pasaman Bara. Dari hasil penelitian ini ternyata siswa yang memiliki Motivasi Belajar tinggi sebesar 63,3\% dan siswa yang memiliki Motivasi belajar cukup sebesar 56,67\%. Dimana rata-rata siswa memiliki motivasi belajar yang tinggi.

Hasil penelitian sejalan dengan Emestin (2007) bahwa siswa SMP Pangudi Luhur dapat diketahui tingkat motivasi belajar dalam kategori sangat tinggi 25 siswa , kategori tinggi 25 siswa, kategori sedang 19 siswa, kategori rendah 11 siswa, dan kategori sangat rendah 10 siswa. Dimana kategori penilaian maka rata-rata (mean) data motivasi belajar sebesar 67,97 dapat disimpulkan bahwa motivasi siswa-siswi SMP Pangudi Luhur termasuk dalam kategori tinggi.
Hubungan Kontrol Diri Dengan Motivasi Belajar Anak Usia Remaja

Hasil uji hipotesis dengan menggunakan Mann-Whiney menunjukkan $p$ value sebesar 0,006 sehingga dapat diambil kesimpulan bahwa Ho ditolak dan $\mathrm{Ha}$ diterima yang artinya ada hubungan yang signifikan antara kontrol diri terhadap motivasi belajar anak usia remaja smp disekolah master depok. Kemudian, dari nilai OR yang diperoleh dapat disimpulkan bahwa kontrol diri tinggi dan motivasi belajar tinggi dapat berpeluang sebesar yaitu 3,750 .

Prestasi menjadi sesuatu yang sangat penting bagi remaja dan remaja mulai menyadari bahwa saat inilah mereka dituntut untuk menghadapi kebutuhan, sebagai upaya yang bukan saja mendapatkan manfaat yang besar pendidikan juga merupakan salah satu kebutuhan pokok remaja yang sering dirasakan belum memenuhi harapan karena rendahnya motivasi (Resty dan Tri, 2010).

Motivasi belajar merupakan kekuatan yang dapat menjadi tenaga pendorong bagi siswa dalam mendayahgunakan potensi-potensi yang ada didalam dan diluar dirinya untuk mewujudkan tujuan belajar. Rendahnya motivasi merupakan masalah dalam belajar karena memberikan dampak bagi prestasi. 
Menyatakan bahwa individu yang mempunyai kontrol diri tinggi berkorelasi dengan adanya penyesuaian yang lebih baik, lebih bisa mengatur emosi secara optimal, kurangnya patologi dan dapat menjalin hubungan dengan orang lain (Sarlito, 2010)

Penelitian ini sejalan dengan Septy Anugrah Heni (2012) dengan berjudul Hubungan antara Kontrol diri dan syukur dengan perilaku konsumtif pada remaja SMA IT Abu Bakar Yogyakarta, hasil penelitian dengan $p$ value yang didapatkan sebesar $0,009(\mathrm{p}<0,05)$ maka terdapat hubungan yang signifikan Hubungan antara Kontrol diri dan syukur dengan perilaku konsumtif pada remaja (Septy, 2013).

Penelitian ini sejalan dengan Andjarwati (2010) dengan berjudul Hubungan harga diri dan optmisme dengan motivasi belajar pada siswa Man Maguwoharjo Sleman Yogyakarta, hasil penelitan dengan $p$ value yang didapatkan sebesar 0,002 $(\mathrm{p}<0,05)$ maka terdapat hubungan yang signifikan Hubungan antara optimisme dengan motivasi belajar (Andjarwati, 2010).

Hasil penelitian dan pembahasan diatas peneliti berasumsi bahwa kontrol diri dengan motivasi belajar anak usia remaja memiliki hubungan yang signifikan disekolah SMP Master Depok. Dan dari nilai OR juga didapatkan bahwa kontrol diri tinggi dan motivasi belajar tinggi dapat berpeluang besar.

\section{SIMPULAN}

Berdasarkan hasil penelitian yang telah dilakukan maka diperoleh kesimpulan bahwa responden pada penelitian ini ratarata usia 14 tahun, mayoritas responden pada penelitian ini berjenis kelamin perempuan, sebagian besar di SMP Master depok memiliki Kontrol diri tinggi dan motivasi belajar tinggi. Terdapat hubungan yang signifikan antara kontrol diri dengan motivasi belajar anak usia remaja smp master Depok.

\section{UCAPAN TERIMA KASIH}

Terima kasih kepada kepala sekolah dan civitas akademia SMP di Sekolah Masjid Terminal Depok serta semua pihak yang telah berperan untuk kelancaran dan kesuksesan dalam penelitian ini. 


\section{DAFTAR RUJUKAN}

Dadang, Hubungan motivasi belajar dengan prestasi belajar program studi keperawatan stikes muhammadiyah lamongan; 2014.

Dini, Hubungan antara kontrol diri dengan perilaku remaja di MTS Negri 3 rajaguluh kabupaten majalengka; 2013.

Donny, Paulina, max. Gambaran tingkat pengetahuan dan status karies gigi pada siswa SMP Kristen 67 Manado; 2015.

Esteria, Hubungan antara persepsi terhadap keterlibatan ayah dan kontrol diri remaja, skripsi. Universitas Gunadarma; 2014.

Eva, Pengaruh penyuluhan terhadap pengetahuan tentang kesehatan reproduksi remaja siswa kelas VII di SMPN 14 Yogyakarta; 2015.

Eviana. Y. Hubungan antara minat belajar, motivasi, lingkungan psikis kampus dan dukungan orang tua terhadap prestasi belajar mahasiswa tingkat III; 2014.

Herasti, Hubungan kontrol diri dengan prokrastinasi akademik pada siswa SMP; 2014.

Kilas Depok. Kualitas pendidikan dikota depok mengalami peningkatan, Diakses 16 Agustus 2017, http://www.kilasdepok.com/2436-2/.

Lailatur, Hubungan antara dukungan orang tua dengan motivasi belajar remaja; 2008.

Metro pendidikan. Mutu pendidikan di Depok belum maksimal, Diakses 16 Agustus

2017 , http://www.metropolitan.id/2016/01/ mutu-pendidikan-di-depok-belummaksimal/.

Molazem,ddk. Dalam: Kharisma, Maya Putri. Hubungan Kadar Albumin Serum Dengan Penyembuhan Luka Sectio Caesarea di RS PKU Muhammadiyah Gamping Yogyakarta. Karya Tulis Ilmiah; 2016.

Nediawati, Hubungan antara dukungan sosial keluarga dengan motivasi belajar pada siswa SMP; 2016.

Notoadmodjo, S. Metodelogi Penelitian Kesehatan. Jakarat: Rineka Cipta; 2015.

Notoadmodjo, S. Metodelogi Penelitian Kesehatan. Jakarta: Rineka Cipta; 2012.

Novi, Pengaruh perilaku teman sebaya terhadap motivasi belajar peserta didik di SMP Negeri 01 Ranah Batahan Kabupaten Pasaman Barat; 2010.

Partini dan Rifai, Peran keluarga dalam menambahkan motivasi belajar remaja; 2012.

Resti dan Tri, Hubungan antara kontrol diri dengan kecenderungan kecanduan media sosial pada remaja akhir; 2010.

Sarlito W. Sarwono, Psikologi remaja, PT RajaGrafindo Persada, Jakarta; 2010.

Septy. Hubungan Kontrol diri dan syukur dengan perilaku konsumtif pada remaja SMA IT abu bakar yogyakarta; 2013. 